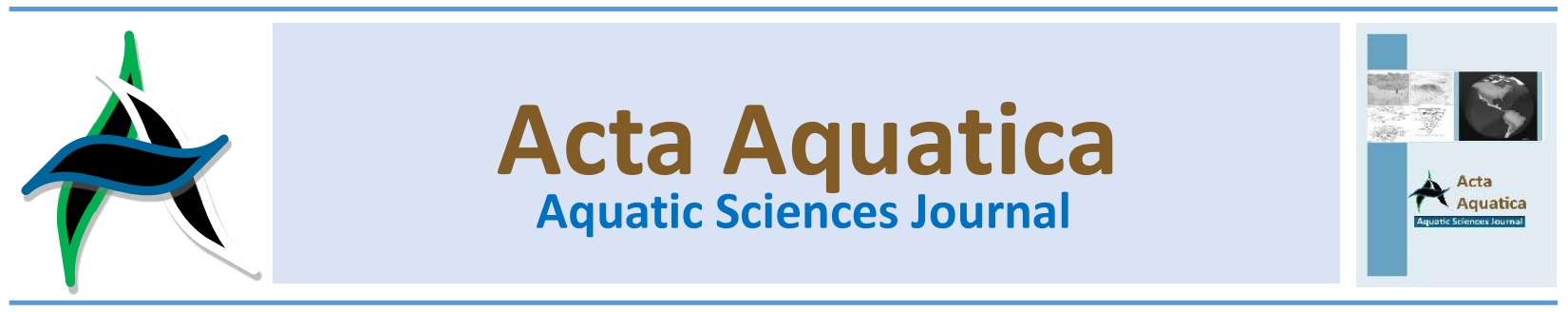

\title{
Growth, Mortality and Exploitation Rate of Pagellus bellottii Harvested from the Marine Territorial Waters of Sierra Leone
}

\author{
Komba Jossie Konoyima* , Lahai Duramany Seisay ${ }^{b}$ \\ anstitute of Marine Biology and Oceanography, University of Sierra Leone, Freetown, Sierra Leone \\ ${ }^{b}$ Ministry of Fisheries and Marine Resources, Youyi Building, Freetown, Sierra Leone
}

\begin{abstract}
Abstrak
Studi ini mengeksplorasi aspek pertumbuhan, mortalitas dan tingkat eksploitasi Pagellus bellottii yang dikumpulkan dari Sierra Leone, yang bertujuan untuk menjembatani kesenjangan pengetahuan dan mendukung manajemen stok yang efisien. Sebanyak 8.216 spesimen Pagellus bellottii dikumpulkan dari Januari-November 2016 dengan menggunakan teknik sampling acak di atas kapal pukat demersal. Data dianalisis menggunakan perangkat lunak FiSAT II yang terkomputerisasi menggunakan frekuensi panjang yang dikumpulkan dalam ukuran kelas yang konstan. Parameter pertumbuhan memberikan panjang asimtotik $\left(L_{\infty}=33.63 \mathrm{~cm}\right)$, laju pertumbuhan $\left(K=0.63 \mathrm{yr}^{-1}\right)$, indeks kinerja pertumbuhan $(\phi=2.85)$, usia teoritis (hingga = 0.6 tahun) dan masa hidup ( $\operatorname{tmax}=5.50$ tahun) sedangkan panjang $\left(L_{m 50}\right)$ dan umur $\left(t_{m 50}\right)$ saat matang gonad pertama diperkirakan masing-masing $22,40 \mathrm{~cm}$ dan 2,30 tahun. Selain itu, tingkat kematian akibat penangkapan ikan saat ini $\left(F=6.58 \mathrm{yr}^{-1}\right)$ melebihi tingkat kematian optimum (Fopt $\left.=0.50 \mathrm{yr}^{-1}\right)$, pembatasan $\left(\mathrm{F}_{\text {limit }}=0.81 \mathrm{yr}^{-1}\right)$ dan tingkat kematian alami $(\mathrm{M}=$ $\left.1.22 \mathrm{yr}^{-1}\right)$, tingkat eksploitasi saat ini adalah (Ecurrent) $0.84 \mathrm{yr}^{-1}$. Hasil menggambarkan harapan hidup rendah, pertumbuhan cepat dan keterlambatan matang gonad pada Pagellus bellottii $\left(L_{m 50}=33,4 \%\right.$, tetapi $\left.<L_{\infty}\right)$. Selain itu, stok $P$. bellottii dieksploitasi secara berlebihan ( $E_{\text {current }}>0,5$ ), ditopang oleh kematian penangkapan ikan yang mengkhawatirkan saat ini di luar batas optimal dan yang diizinkan. Ini sangat mengkhawatirkan dan tingkat eksploitasi saat ini harus dikurangi menjadi $0,5 \mathrm{yr}^{-1}(40,5 \%)$ dan tingkat kematian penangkapan ikan menjadi $0,5 \mathrm{yr}^{-1}(92,4 \%)$ untuk mencapai setidaknya tingkat eksploitasi yang optimal $\left(E_{\text {current }}=0,5\right)$ dan tingkat kematian penangkapan ikan $\left(F_{\text {current }}=F_{\text {opt }}\right)$ secara berturut-turut, melalui lembaga penutupan musim penangkapan ikan dan pengurangan armada yang menangkap spesies tersebut.
\end{abstract}

Kata kunci: Eksploitasi; pertumbuhan; masa hidup; kematian

\section{Abstract}

The study investigated growth, mortality and exploitation rate of Pagellus bellottii collected off Sierra Leone, aimed to support efficient management of its stock. A total of 8, 216 specimens of Pagellus bellottii were collected at random from JanuaryNovember, 2016 on-board a demersal trawler. Data analysis employed methods implemented in the computerized FiSAT II software using pooled length-frequencies in constant class size. Growth parameters gave asymptotic length $\left(L_{\infty}=33.63 \mathrm{~cm}\right)$, growth rate $\left(K=0.63 \mathrm{yr}^{-1}\right)$, growth performance index $(\phi=2.85)$, theoretical age ( $\left.t_{o}=-0.6 y e a r s\right)$ and life-span ( $t_{\max }=5.50$ years) whereas the length $\left(L_{m 50}\right)$ and age $\left(t_{m 50}\right)$ at first maturity were estimated as $22.40 \mathrm{~cm}$ and 2.30 years respectively. Besides, the current fishing mortality rate $\left(F=6.58 \mathrm{yr}^{-1}\right)$ exceeded the optimum $\left(F_{\mathrm{opt}}=0.50 \mathrm{yr}^{-1}\right)$, limiting $\left(\mathrm{F}_{\text {limit }}=0.81 \mathrm{yr}^{-1}\right)$ and natural $\left(\mathrm{M}=1.22 \mathrm{yr}^{-1}\right)$ mortality rates, and the current exploitation rate $\left(\mathrm{E}_{\text {current }}\right)$ was $0.84 \mathrm{yr}^{-1}$. Results depicted low life expectancy, fast growth and late first maturity $\left(L_{m 50}=33.4 \%\right.$, but $\left.<L_{\infty}\right)$ in Pagellus bellottii. Also, the stock of $P$. bellottii was overexploited $\left(\mathrm{E}_{\text {current }}>0.5\right)$, buttressed by the alarming current fishing mortality beyond optimal and permissible limits. This was very worrisome and the current exploitation rate should be reduced to $0.5 \mathrm{yr}^{-1}(40.5 \%)$ and fishing mortality rate to $0.5 \mathrm{yr}^{-1}(92.4 \%)$ in order to achieve at least optimal level of exploitation ( $E_{\text {current }}=$ 0.5 ) and fishing mortality rate $\left(F_{\text {current }}=F_{\text {opt }}\right)$ respectively, through institution of closed fishing seasons and reduction in fleets targeting the species.

Keywords: Exploitation; growth; life-span; mortality; stock

\footnotetext{
* Correspondence: Institute of Marine Biology and Oceanography, Fourah Bay College, University of Sierra Leone, Freetown, Sierra Leone. Tel: +23278798929

e-mail: konoyimak@gmail.com
} 


\section{Introduction}

Pagellus bellottii (Steindachner, 1882) is commonly known as the red Pandora, a demersal fish species of the Sparidae family that inhabit hard or sandy bottoms in coastal marine waters at depths between $10 \mathrm{~m}$ and $50 \mathrm{~m}$ but could move up to $250 \mathrm{~m}$ depth (Kouame et al., 2018). The red Pandora is known to occur in the Gulf of Guinea (Fischer et al., 1987) with wide distribution in the Eastern Atlantic (Bauchot and Hureau, 1986). Besides, Pagellus bellottii is one of most economically important and diverse marine teleost of the West African Coast (Kouame et al., 2018), and constitutes a critical component of the multi-species coastal demersal fisheries in Sierra Leone (Showers,1995; Seisay 2014) and the Eastern Central Atlantic (Russell and Carpenter, 2014). Further, Pagellus bellottii comprised $0.72 \%$ at $0-30 \mathrm{~m}, 5.66 \%$ at $31-50 \mathrm{~m}, 4.69 \%$ at $51-100 \mathrm{~m}$ and $12.65 \%$ at $101-200 \mathrm{~m}$ depth zones of ten commercially important demersal fish species in Sierra Leone (Seisay, 2014).

Biological studies are known to provide unwavering information for fisheries resources management (Amponsah et al., 2017; Konoyima et al., 2020). Study of fish growth inform of the instantaneous growth rate, growth performance and age (Ghanbarzadeh et al., 2015; Baset et al., 2020), whereas mortality and exploitation rates provide invaluable information about the status of fish stocks, required for recalibrating management measures for exploitation within efficient limit (Amponsah et al., 2016; 2017; Asadollah et al., 2017; Wehye et al., 2017; Baset et al., 2020).

However, despite the significant economic and dietary provisions of Pagellus bellottii in Sierra Leone (Neiland et al., 2016), study of the status of its stock has not gained the needed attention in academia. The objective of the present study was to explore the growth, mortality and exploitation rate of Pagellus bellottii in the marine territorial waters of Sierra Leone and the implications for resource sustainability. The following questions were addressed: Did the fish grow in accordance with specified growth model? What kind of growth pattern did Pagellus bellottii exhibit? At what length and age did the fish attain first maturity? What was the theoretical age and life-span of Pagellus bellottii? Was the stock of Pagellus bellottii subjected to fishing pressure and overexploitation? This paper will be unique to Sierra Leone, and will be invaluable to decision makers for instituting the needed sustainability plans for such a critically important fish.

\section{Materials and Methods}

\subsection{Study Area}

Sierra Leone lies between latitudes $7^{\circ} 10^{\prime} \mathrm{N}$ and longitudes $10^{\circ} 14^{\prime} \mathrm{W}$ on the West Coast of Africa, covering an area of $71,740 \mathrm{~km}^{2}$ (Coutin and Payne, 1989). The Continental Shelf is about $30000 \mathrm{~km}^{2}$ and an Exclusive Economic Zone (EEZ) of about 155, $700 \mathrm{~km}^{2}$ (Neiland et al., 2016). The climate in Sierra Leone is comprised of the dry season (November-April) and the rainy season (May-October, Coutin and Payne, 1989). Mean monthly temperatures for the open continental shelf area range from $26^{\circ} \mathrm{C}-27^{\circ} \mathrm{C}$ and $28^{\circ} \mathrm{C}-29^{\circ} \mathrm{C}$ for the wet and dry season respectively (Coutin and Payne, 1989). Fig. 1 illustrates the sampling areas in the marine territorial waters of Sierra Leone.

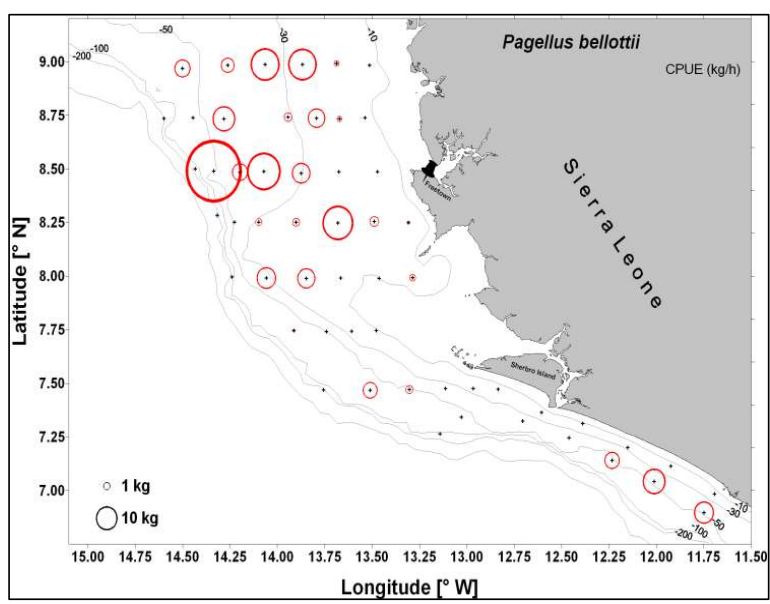

Figure 1. Sampling areas for Pagellus bellottii in the Marine Territorial Waters of Sierra Leone

\subsubsection{Collection of Data}

Monthly fish samples were collected from a commercial trawler in the inner $(10-50 \mathrm{~m})$ and outer $(50-100 \mathrm{~m})$ shelf of the Sierra Leone coast, and trawl duration was standardized to $6 \mathrm{hrs}$ at night. Fish samples were collected from January-November, 2016 as recommended for reliable analysis of the dynamics of a fish population (Pauly, 1980).

Pagellus bellottii was identified based on its distinct meristic and morphometric characteristics using a guide for the Gulf of Guinea (FAO, 2010). Once the catch was hauled on deck, sample collection was random, following recommended methods for fish sampling on-board a demersal trawler (Pauly 1980), and a total of 8,216 specimens of the assessed species were collected altogether. The collected specimens were frozen and later taken to the laboratory of the Institute of Marine Biology and Oceanography, Fourah Bay College, University of Sierra Leone for biological analysis, and total length of the study species was measured using a one-meter fish measuring board graduated in centimeters.

\subsubsection{Data Analysis}

Estimation of growth, mortality and exploitation parameters was completed using methodologies fitted in the computerized FAO Fish Stock Assessment Tool (FiSAT II) software (Gayanilo et al., 2005) that requires time series of length frequencies data grouped by constant class size.

Least square regression analysis of length and weight was completed using the MS Excel (Vers. 2010) computer package, and the correlation coefficient $(r)$ was calculated by the relation: $r=\operatorname{SQRT}\left(R^{2}\right)$, where ' $R^{2 '}$ is the coefficient of determination obtained from the least square regression length-weight relationship (Konoyima, 2020; Konoyima et al., 2020).

\subsubsection{Estimation of Parameters}

\subsubsection{Growth Parameters}

The asymptotic length $\left(\mathrm{L}_{\infty}\right)$ was computed using the Powell-Witherall method (Powell, 1979; Wetherall, 1986) as implemented in the FiSAT II routine (Gayanilo et al., 2005), while the asymptotic weight $\left(W_{\infty}\right)$ was estimated using an empirical model (Pauly, 1984):

$$
\begin{gathered}
\log \mathrm{W}_{\infty}=\log \mathrm{M}+0.0066-0.6543 \log \mathrm{K}- \\
0.4634 \log \mathrm{T} /-0.279 \ldots \ldots \ldots \ldots \ldots . .(1) .
\end{gathered}
$$


The length-weight relationship followed the method of least square regression equation (Pauly, 1983; 1984):

$$
\mathrm{W}=a L^{\mathrm{b}}
$$

(Where $\mathrm{W}=$ Body weight $(\mathrm{g}), \mathrm{L}=$ total length $(\mathrm{cm}), \mathrm{b}=$ regression coefficient/growth exponent and $\mathrm{a}=$ intercept).

The instantaneous growth rate $(K)$ was estimated by method of $\mathrm{K}$-Scan (using $\mathrm{L} \infty$ as input parameter) in ELEFAN 1 fitted in FiSAT II routine (Gayanilo et al., 2005) whereas the growth performance index $(\phi)$ was estimated from an empirical equation (Pauly and Munro, 1984):

$$
\phi=\log 10 \mathrm{~K}+2 \log 10\left(\mathrm{~L}_{\infty}\right)
$$

Following the method of K-Scan in ELEFAN1 (Gayanilo et al., 2005), the von-Bertalanffy growth curves with superimposed length-frequency plots were obtained. Moreover, the special von Bertalanffy growth function (Pauly, 1984) was used to illustrate growth in length of the assessed fish thus:

$$
L_{t}=L_{\infty}\left(1-e^{-K^{(t-t o)}}\right)
$$

(Where $\mathrm{L}_{\infty}=$ asymptotic length, $\mathrm{K}=$ instantaneous growth rate. $t_{0}=$ age of the fish at length of zero, $L_{t}=$ length at age $t$ and $t=$ age at length). The theoretical age at length zero $\left(t_{0}\right)$ was estimated using an empirical model (Pauly, 1979):

$$
\log _{10}\left(-\mathrm{t}_{0}\right)-0.392-0.275 \log 10 \mathrm{~L}_{\infty}-1.038 \log 10 \mathrm{~K} .
$$

The life-span of the fish ( $\left.t_{\max }\right)$ was calculated using a simple expression (Pauly, 1984) thus:

$$
\mathrm{t}_{\max }=\frac{2.9957}{\mathrm{~K}}+t_{0 \ldots \ldots \ldots \ldots \ldots(1)}
$$

The length at first maturity $\left(L_{m 50}\right)$ is the length at which $50 \%$ of the assessed fish reached first maturity, and was estimated using a model requiring only $L_{\infty}$ as input parameter (Hoggarth et al., 2006):

$$
\mathrm{L}_{\mathrm{m} 50}=\frac{2 * \mathrm{~L}_{\infty}}{3}
$$

The age at first maturity $\left(t_{m 50}\right)$ was calculated using the age at length equation (Goonetileke and Sivasubramania, 1987) thus:

$$
\mathrm{t}_{\mathrm{m} 50}=\frac{-1}{\mathrm{~K}} * \operatorname{Ln}\left(1-\frac{\mathrm{L}_{\mathrm{m} 50}}{\mathrm{~L}_{\infty}}\right)+\mathrm{t}_{0} \ldots \ldots \ldots \ldots \text { (8). }
$$

\subsubsection{Mortality and Exploitation Rates}

The instantaneous natural mortality rate (M) was estimated from Pauly's empirical formula (Pauly, 1980) as implemented in the FiSAT II routine using mean surface temperature $(\mathrm{T})$ of $27^{\circ} \mathrm{C}, \mathrm{L}_{\infty}$ and $\mathrm{K}$ as input parameters thus:

$$
\begin{gathered}
\log M=-0.0066-0.2791 \log \mathrm{L}_{\infty}+0.6543 \log \mathrm{K}+ \\
0.4634 \log \mathrm{T} \ldots \ldots \ldots \ldots \ldots \ldots \ldots \ldots \ldots
\end{gathered}
$$

The total instantaneous mortality rate (Z) was calculated from the method of length converted catch curve fitted in the FiSAT II routine (Gayanilo et al., 2005) using ' $M$ ' and ' $T$ ' as input parameters. This procedure further provided estimate of the instantaneous fishing mortality rate (F) and current exploitation ratio ( $\left.E_{\text {current }}\right)$. However, the optimum fishing mortality rate $\left(F_{\text {opt }}\right)$ was estimated using a simple expression (Pauly, 1984):

$$
\mathrm{F}_{\mathrm{opt}}=0.4 * \mathrm{M}
$$

Also, the limiting fishing effort $\left(F_{\text {limit }}\right)$ was estimated using formula by Patterson (1992):

$$
\mathrm{F}_{\text {limit }}=\frac{2 * \mathrm{M}}{3}
$$

\section{Results and Discussion}

\subsection{Results}

\subsubsection{Growth Parameters}

The total length of the largest specimen of Pagellus bellottii $\left(\mathrm{L}_{\max }\right)$ was $28 \mathrm{~cm}$ and the asymptotic length $\left(\mathrm{L}_{\infty}\right)$ was estimated as $33.63 \mathrm{~cm}$ (Fig. 2).

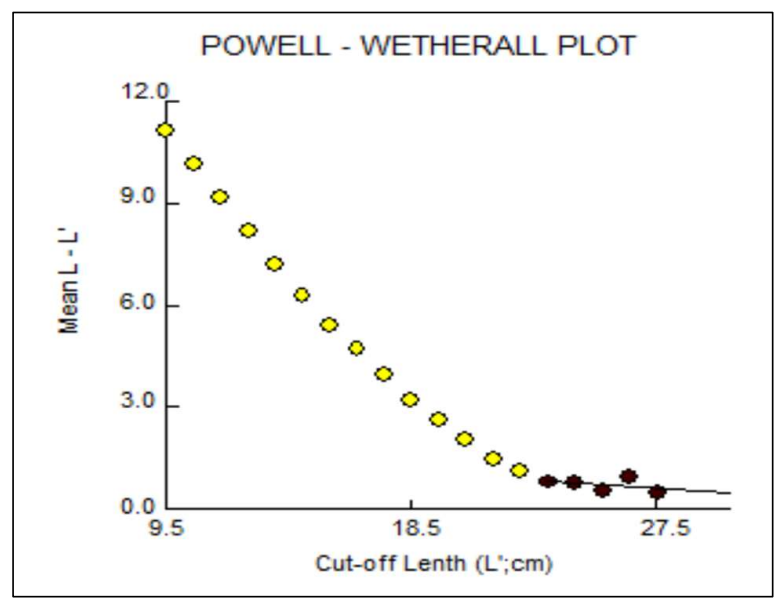

Figure 2. FiSAT II output of the Powell-Witherall plot for Estimating $\mathrm{L}_{\infty}$ and $\mathrm{Z} / \mathrm{K}$ of Pagellus bellottii

Similarly, the total weight of the largest specimen $\left(W_{\max }\right)$ was $286.29 \mathrm{~g}$ and the asymptotic weight $\left(\mathrm{W}_{\infty}\right)$ was estimated as $4.82 \mathrm{~kg}$ (4 $820 \mathrm{~g})$. The least square regression length-weight relationship for $P$. bellottii was defined as:

$W=0.03 \mathrm{~L}^{2.75}$, and length positively correlated with weight $(r=0.96)$. Moreover, growth in length of Pagellus bellottii was defined by the special Von Bertalanffy Growth Function (VBGF) thus:

$$
\mathrm{L}_{\mathrm{t}}=33.63\left(1-e^{-0.63(\mathrm{t}+0.6)}\right)
$$
VBGF as:

Similarly, growth in weight was predicted for the special

$$
\mathrm{W}_{\mathrm{t}}=4.82 \mathrm{~kg} \cdot\left(1-e^{-0.63(\mathrm{t}+0.6)}\right)^{2.75}
$$

The growth rate $(K)$, growth performance index $(\phi)$, theoretical age $\left(t_{0}\right)$ and longevity $\left(t_{\max }\right)$ of the assessed species were 0.63 year $^{-1}, 2.85,-0.6$ years and 5.4 years respectively. The length at first maturity $\left(L_{m 50}\right)$ and age at first maturity $\left(t_{m 50}\right)$ were estimated as $22.40 \mathrm{~cm}$ and 2.30 years respectively. Further, the von Bertalanffy growth curves of $P$. bellottii with superimposed length-frequencies are given in Fig. 3. 


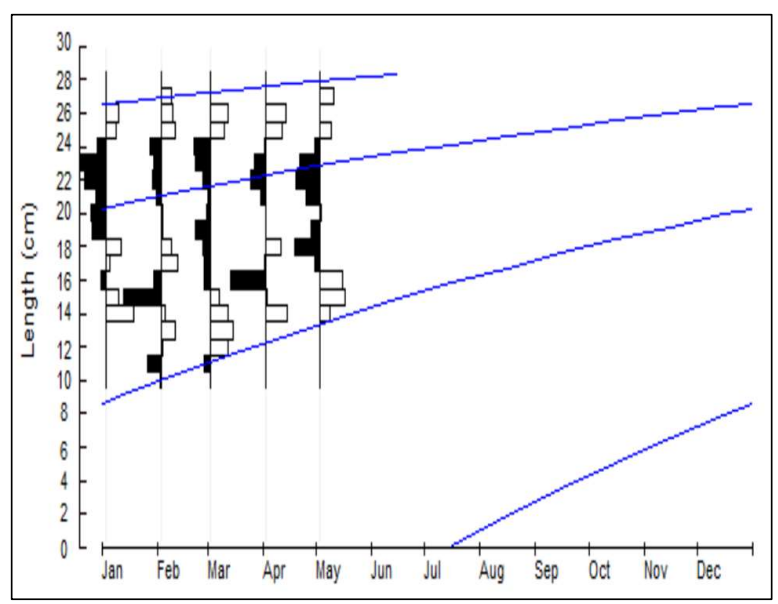

Figure 3. FiSAT II output of the von Bertalanffy growth curves with superimposed length-frequencies of Pagellus bellottii

\subsubsection{Mortality and Exploitation rates}

Estimates of the instantaneous total mortality (Z), natural mortality (M), instantaneous fishing mortality (F) and the current exploitation rate are provided in the length converted catch curve (Fig. 4).

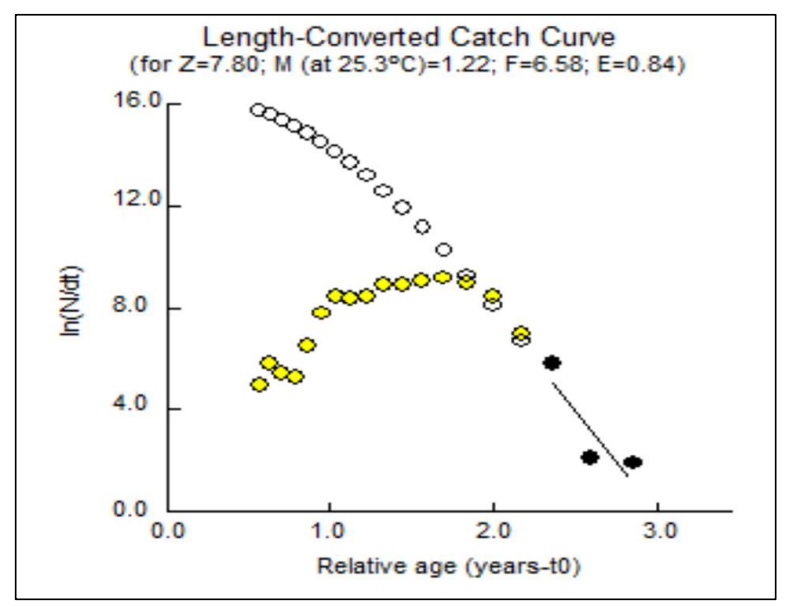

Figure 4. FiSAT II output of length-converted catch curve of Pagellus bellottii

The optimum fishing mortality rate $\left(\mathrm{F}_{\mathrm{opt}}\right)$ and limiting fishing mortality rate $\left(F_{\text {limit }}\right)$ were estimated as 0.50 year $^{-1}$ and 0.81 year $^{-1}$ respectively.

\subsection{Discussions}

\subsubsection{Growth Parameters}

The colossal difference between the estimated asymptotic sizes and the maximum recorded sizes $\left(\mathrm{L}_{\infty}, \mathrm{W}_{\infty}>\right.$ $\mathrm{L}_{\max }, \mathrm{W}_{\text {max }}$ ) from this study indicated that size growth in Pagelus bellottii firmly followed the special von Bertalanffy model (Pauly, 1984), and the asymmetric growth between length and weight $(b<3.0)$ portrayed a negative allometric growth pattern in the study species (Pauly, 1983; 1984; Konoyima, 2020; Konoyima et al., 2020). According to Pauly (1984), tropical fish species with $\mathrm{L}_{\infty}<50 \mathrm{cmTL}$ implies that such fish could hardly grow to $50 \mathrm{~cm}$ TL. Moreover, the calculated growth rate $(\mathrm{K})$ and growth performance index $(\phi)$ of the assessed species were very much characteristic of fast growing tropical species whereby ( $K=0.33$ year $^{-1}-0.67$ year $^{-1}$, Kienzle, 2005) and $(\phi=$ 2.65-3.32, Baijot et al., 1997; Montchowui et al., 2011). It could be that growth conditions were very much within favourable limit throughout the study period, buttressed by the estimated low natural mortality rates (M) from this study. Comparatively, the estimated asymptotic length $\left(L_{\infty}\right)$, growth rate $(K)$ and growth performance index $(\phi)$ of $P$. bellottii from this study surpassed observed values for the species collected off Ghana (Amponsah et al., 2016: $\mathrm{L}_{\infty}=19.43 \mathrm{cmTL}, \mathrm{K}=0.42 \mathrm{yr}^{-1}, \phi=2.2$; Rijavec, 1973: $\mathrm{L}_{\infty}=30.76 \mathrm{cmTL}, K=0.44 \mathrm{yr}^{-1}$; Koranteng and Pitcher, 1987: $\left.\mathrm{L}_{\infty}=28.6 \mathrm{~cm} \mathrm{TL}, K=0.38 \mathrm{yr}^{-1}\right)$, off Mauritania (Yarba et al., 2004: $L_{\infty}=28.96 \mathrm{cmTL}, K=0.31 \mathrm{yr}^{-1}$ ), but closely related to the observed value off Ghana (Asabere-Araeyaw and Bay, 1999: $\left.L_{\infty}=34.2 \mathrm{cmTL}, K=0.53 \mathrm{yr}^{-1}\right)$. However, higher asymptotic length $\left(L_{\infty}>37 \mathrm{~cm}\right.$ but $<42 \mathrm{~cm}$ ) has been noted for the assessed species collected off Ghana and Western Sahara (Phan and Kompowski, 1972) and off Senegal (Tomlinson and Abramson, 1981; Franqueville, 1983). Variation in habitat conditions, seasons and geographical location could alter growth indices in a fish (Amponsah et al., 2016, 2017; Asadollah et al., 2017; Baset et al., 2020; Konoyima et al., 2020).

Moreover, the estimated length $\left(L_{m 50}\right)$ and age $\left(t_{m 50}\right)$ at first maturity were suggestive of late first maturity in $P$. bellotii whereby individuals attained large sizes $\left(L_{m 50}=33.40 \%<L_{\infty}\right)$ prior to first maturity, and the age at first maturity was $58.1 \%<$ $t_{\max }$, strengthening the initial postulate of a fast growing fish. A similar length at first maturity has been observed in $P$. bellottii off Ghana $\left(L_{m 50}=21 \mathrm{~cm}\right.$, Asabere-Ameyaw, 2000), and a lower $L_{m 50}$ has also been recorded off Ghana (Rijavec, 1973: $L_{m 50}$ $=13.06 \mathrm{~cm}$; Koranteng and Pitcher, 1987: $L_{m 50}=19.5 \mathrm{~cm}$; Amponsah et al., 2016: $L_{m 50}=13 \mathrm{~cm}$ ).

Further, the estimated life-span $\left(t_{\max }\right)$ of $P$. bellottii in the present study portrayed low life expectancy of the species, and was similar to other records for the species off Ghana (Rijavec, 1973: $t_{\max }=6-7$ years; Koranteng and Pitcher, 1987: $t_{\max }=6 y e a r s ;$ Asabere-Araeyaw and Blay, 1999: $t_{\max }=6$ years), but slightly below another recorded value off Ghana (Amponsah et al., 2016: $t_{\max }=7$ years). Also, the estimated theoretical age $\left(t_{0}\right)$ of the assessed species suggested that the fish spent half a year in its early-life stages before metamorphosing to the age group of immature individuals $(<2.3$ years). The estimated theoretical age $\left(t_{0}\right)$ in the present study was similar to that recorded off Western Sahara (Phan and Kompowski, 1972: $\mathrm{t}_{0}=-$ 0.63 years) and off Ghana (Koranteng and Pitcher, 1987: $t_{0}=-$ 0.59 ), while much lower value has been observed off Ghana (Amponsah et al., 2016: $t_{0}=-0.44$ years), off Senegal (Franqueville, 1983: $t_{0}=-0.11$ years) and off Mauritania (Yarba et al., 2004: $\mathrm{t}_{0}=-0.008$ years). Nonetheless, ' $\mathrm{t}_{0}$ ' can get much higher for P. bellottii (Phan and Kompowski, 1972: $t_{0}=-$ 0.81years off Senegal; Koranteng and Pitcher, 1987: $\mathrm{t}_{0}=-$ 1.45 years off Ghana). Regional differences in growth conditions could be the plausible prime mover of variability in age of the species.

\subsubsection{Mortality and Exploitation rates}

In the present study, the instantaneous fishing mortality rate (F) of Pagellus bellotti was overly alarming, and exceeded the optimum $\left(\mathrm{F}_{\mathrm{opt}}\right)$, limiting $\left(\mathrm{F}_{\text {limit }}\right)$ and natural $(\mathrm{M})$ mortality rates. Besides, the estimated current exploitation rate ( $\left.E_{\text {current }}\right)$ exceeded limit $\left(E=0.5 y r^{-1}\right)$ for optimally exploited fish stocks (Beverton and Holt, 1957; Gulland, 1971; Pauly, 1987). This indicated that the stock of $P$. bellottii in the marine territorial waters of Sierra Leone was subjected to tremendous fishing pressure and was overexploited. The current fishing mortality rate $(F)$ should be reduced to a rate of $0.5 \mathrm{yr}^{-1}(92.4 \%)$ and the 
current exploitation rate $\left(\mathrm{E}_{\text {current }}\right)$ to $0.5 \mathrm{yr}^{1}(40.5 \%)$ in order to achieve at least an optimal fishing mortality rate $\left(\mathrm{F}_{\text {current }}=\mathrm{F}_{\mathrm{opt}}\right.$, Gulland, 1971) and exploitation rate $\left(E_{\text {current }}=0.5\right.$, Pauly 1984) respectively. This can be achieved by instituting closed fishing seasons and/or reducing fleets or fishing periods of fleets targeting the species. Besides, it was very interesting to note that such deplorable condition of the stock of $P$. bellotii extended beyond Sierra Leone as a recent study has revealed an unhealthy state of the stock of $P$. bellottii in the Ghanaian waters (Amponsah et al., 2016: $E=0.57 \mathrm{yr}^{-1}, \mathrm{~F}=1.48 \mathrm{yr}^{-1}$; ). Earliest records had also shown an overexploited stock of the study species $\left(E=0.8 \mathrm{yr}^{-1}, \mathrm{~F}=2.09 \mathrm{yr}^{-1}\right.$, Caveriviere and Thiam, 1993 off Senegal; $E=0.7 \mathrm{yr}^{-1} ; \mathrm{F}=2.61 \mathrm{yr}^{-1}$, Asabere-Araeyaw and Blay, 1999 off Ghana). Such consistent trend in unhealthy status of the stock of $P$. bellotti over the years suggested that the needed concern has not been giving to its sustainability, and this should serve as a whistle blower to decision makers in order to prevent a potential non-recovery state of such critically important stock (Pauly, 1989).

Also, the $\mathrm{Z} / \mathrm{K}$ ratio $(\mathrm{Z} / \mathrm{K}=2.74)$ of $P$. bellottii from this study climaxed the proposed safe limit $(\mathrm{Z} / \mathrm{K}=2.0$, King and Etim, 2004; Wehye et al., 2017; Amposah et al., 2016; 2017), strengthening the postulate of an exploited stock beyond optimal limit. Besides, a $\mathrm{Z} / \mathrm{K}$ ratio $>1$ is indicative of a mortality dominated stock (Barry and Tegner, 1989). The $Z / K$ ratio from this study further portrayed an $r$-configured tropical species $(\mathrm{Z} / \mathrm{K}>2.0)$ whereby larger sized specimens of the study species declined in number (Figure 3; Johnson, 1981; Pauly, 1984).

\section{Conclusions}

Pagellus bellottii was of low life expectancy, fast growth and late first maturity $\left(L_{m 50}=33.4 \%<L_{\infty}\right)$. Also, the stock of $P$. bellottii in the Marine Territorial Waters of Sierra Leone suffered tremendous fishing pressure $\left(\mathrm{F}>\mathrm{F}_{\text {opt }}\right)$ and was overexploited ( $E_{\text {current }}>0.5$ ). The current fishing mortality rate (F) should be reduced to a rate of $0.5 \mathrm{yr}^{-1}(92.4 \%)$ and the current exploitation rate (Ecurrent) to $0.5 \mathrm{yr}^{-1}(40.5 \%)$ in order to achieve at least an optimal fishing mortality rate $\left(F_{\text {current }}=F_{\text {opt }}\right)$ and exploitation rate $\left(\mathrm{E}_{\text {current }}=0.5\right)$ respectively. This can be achieved by instituting closed fishing seasons and/or reducing fleets targeting the species. Moreover, $P$. bellottii belonged to the category of tropical $r$-configured fish species with $Z / K>2.0$.

\section{Acknowledgements}

The authors are grateful to the Ministry of Fisheries and Marine Resources, Sierra Leone and the Institute of Marine Biology and Oceanography, Fourah Bay College, University of Sierra Leone for providing the opportunity to undertake the study.

\section{Bibliography}

Amponsah, S.K.K., Ofori-Danson, PK, Nunoo, FKE, Ameyaw, GA, 2017. Aspects of population dynamics of Red Pandora, Pagellus bellottii (Steindachner, 1882) from the coastal waters of Ghana. Journal of Scientific and Innovative Research 5, 215-224.

Amponsah, SKK., Ofori-Danson, PK, Nunoo, FKE, 2016. Study of the population parameters of the bigeye grunt, Brachydeuterus auritus (Valenciennes, 1831) in Ghanaian coastal waters and its implications for management. International Journal of Fisheries and Aquatic Studies 4, 413-419.

Asabere-Ameyaw, A, 2000. Aspects of the reproductive biology of the Red Pandora, Pagellus bellottii (Pisces: Sparidae) in Ghana. Journal of the Ghana Science Association 2, 23-30.
Asabere-Ameyaw A, Blay, J, 1999. Growth and mortality parameters of Pagellus bellottii (Sparidae) in the Cape Coast area of Ghana. Journal of the Ghana Science Association 1, 53-62.

Asadollah, S., Soofiani, NM, Keivany, Y, Hatami, R, 2017. Age and growth of the mesopotamian barb, Capoeta damascina, in Central Iran. Iranian Journal of Fisheries Science 16, 511-521.

Baijot, E., Moreau, J, Bouda, S, 1997. Hydrological Aspects of Fisheries in Small Reservoirs in the Sahel Region. Centre for Agricultural and Rural Cooperation, Netherlands. pp. 79-109.

Barry, JP, Tegner, MJ, 1989. Inferring demographic processes from size frequency distributions: simple models indicate specific patterns of growth and mortality. US Fisheries Bulletin 88, 13-19.

Baset, A., Qun, L, Baochao, L, Abdul, W,Imtiaz, A, Han, Y, Qingqing, Z, 2020. Population Dynamics of Saddle Grunt Fish, Pomadasys maculatus (Bloch, 1793) from Pakistani Waters, Bioprocess Engineering 4, 1-8. doi: 10.11648/j.be.20200401.11.

Bauchot, ML, Hureau, JC, 1986. Sparidae. In: Whitehead, PJP, Bauchot, ML, Hureau, JC, Nielsen, J, Tortonese, E (Eds.). Fishes of the North-eastern Atlantic and the Mediterranean (FNAM), UNESCO, Paris, pp. 883-907.

Beverton, RJH, Holt, JS, 1957. On the dynamics of exploited fish populations. Fisheries Investment Series 19, pp.533.

Caverivière, A, Thiam, M, 1994. In: Essai d'application d'un modèle global à l'ensemble des espèces démersales côtières du Sénégal. GÉRARD, B (Ed) 2, pp.351-352.

Coutin, PC, Payne, Al, 1989. The effects of long-term exploitation of demersal fish populations off the coast of Sierra Leone, West Africa. Journal of Fish Biology 35, 163-167.

FAO (Food and Agriculture Organization), 2010. Fish and shellfish guide of West Africa. FAO Fisheries Department, Rome.

Fischer, W, Schneider, W, Bauchot, ML, 1987. Sparidae. In: Fiches FAO d' Identification des Especes pour les Besoins de la Pêche - Mediterranée et Mer Noire, Zone de Pêche: Rome: Food and Agriculture Organization. pp. 13430-1363.

Franqueville, C, 1983. Biologie et dynamique des populations des daurades Pagellus bellottii (Steindachner, 1882) le long des côtes Sénégambiennes. 276. Thèse de Doctorat d'Etat, Univ. d'Aix - Marseille.

Gayanilo, FC., Sparre, P, Pauly, D, 2005. Revised FAO-ICLARM computerized fish stock assessment tools II (FiSAT II) and user's guide. Series 8 , revised version. FAO Fisheries Department, Rome.

Ghanbarzadeh, M., Keivany, Y, Soofiani, NM, 2015. Population Dynamics of the Sparid Fish, Argyrops spinifer (Teleostei: Sparidae) in Coastal Waters of the Persian Gulf. Iranian Journal of Science and Technology, Transactions A: Science. doi.10.1007/s40995-017-0259-

Goonetilleke, H, Sivasubramaniam, K, .1987. Separating mixtures of normal distribution: basic programs for Bhattacharya's method and their application for fish population analysis. FAO Fisheries Department, Colombo Sri Lanka, Rome.

Gulland, J, 1971. The Fish Resources of the Oceans. FAO Fishing News Books, Surrey. PP. 255.

Hoggarth, DD., Abeyasekera, S, Arthur, RI, Beddington, JR, Burn, RW, Halls, AS, 2006. Stock Assessment for fishery management - A framework guide to the stock assessment tools of the Fisheries Management Science 
Programme (FMSP). Fisheries Technical Paper 487, FAO Fisheries Department, Rome, PP.261.

Johnson, L, 1981. The thermodynamic origin of ecosystems. Canadian Journal of Fisheries and Aquatic Science 38, 571-590.

Kienzle, MO, 2005. Estimation of the population parameters of the Von Bertalanffy Growth Function for the main commercial species of the North Sea. Rome: FAO Fisheries Department, Rome, pp. 34.

King, RP, Etim, L, 2004. Reproduction, growth, mortality and yield of $T$. mariae (Boulenger, 1899) (cichlidae) in Nigeria rainforest wetland stream. Journal of Applied Ichthyology 20, 502-510.

Konoyima, KJ., Mansaray, A, Ndomahina, ET, Amara, EB, 2020. Length-Weight relationship and condition factor of Coelotilapiajoka (Thys van den Audenaerde 1969) in the Rokel/Seli River, West Africa. International Letters of Natural Sciences 77, 27-40. doi:10.18052/www.scipress.com/ILNS.77

Konoyima, KJ, 2020. Sex ratio, stages of gonad development and growth pattern of Brachydeuterus auritus (Valenciennes, 1832) and Pomadasys jubelini (Curvier, 1830) in Sierra Leone. International Journal of Basic, Applied and Innovative Researh 9, 43-59.

Koranteng, KA, Pitcher, TJ, 1987. Population parameters, biannual cohorts, and assessment in the Pagellus bellottii (Sparidae) fishery off Ghana. Journal du Conseil international pour l'Eploration de la Mer 43, 129-138.

Kouame, AC., Sylla, S, Arra, S, Kouakou, KF, Yao, SS, 2018. Parameters of Reproductive biology of Red Pandora Pagellus bellottii (Steindachner, 1882) in the Ivoirian coast (Cote d'Ivoire). Journal of Biodiversity and Environmental Science 12, 185-193.

Montchowui, E., Chikou, A, Ovidio, M, Laleye, P, Poncin, P, 2011. Population dynamics of Labeo senegalensis (Val, 1842 ) in the Oueme River, Benin. Journal of Fisheries International 6, 52-58.

Neiland, AE., Cunningham, S, Arbuckle, M, Baio, A, Bostock, T, Coulibaly, D, Gitonga, NK, Long, R, Sei, S, 2016. Assessing the potential contribution of fisheries to economic development: The case of post-ebola Sierra Leone. Natural Resources 7, 356-376. http://dx.doi.org/10.4236/nr.2016.76031

Patterson, K, 1992. Fisheries for small pelagic species: an empirical approach to management targets. Revised Fisheries Biology 2, 321-338.

Pauly, D, 1979. Gill size and temperature as governing factors in fish growth: a generalization of von Bertalanffy's growth formula. Berichte des Instituts für Meereskunde an der University, Germany, pp. 156.

Pauly, D, 1980. A selection of simple methods for the assessment of tropical fish stocks. Rome: FAO Fishery Circular, 729, pp.54.

Pauly, D, 1984. Fish population dynamics in tropical waters: a manual for use with programmable calculators. ICLARM Studies Review 8, pp. 325.

Pauly, D, 1983. Linear Regressions in fisheries research. Journal of the Fisheries Research Board of Canada 30, 409-434.

Pauly, D, 1987. A review of the ELEFAN system for analysis of length frequency data in fish and invertebrates. p. 7-34. In: Length-based Methods in Fisheries Research. Pauly, D. Morgan, GR. (Eds.), ICLARM Conference Proceedings 13. ICLARM, Manila.

Pauly, D, 1989. Biology and management of tropical marine fisheries. Resource management and Optimization 6, 253-271.
Powell DG, 1979. Estimation of mortality and growth parameters from the length-frequency in the catch, Rapports et Proces-verbaux des Réunions, CIEM 175: 167-169.

Pauly, D, Munro, JL, 1984. Once more on the comparison of growth in fish and invertebrates. ICLARM Fishbyte PP.21.

Phan, LT, Kompowski, A, 1972. A Study on Pagellus Coupe/ Dieuzeide from The North-West African Region. Acta Hthyologica Et Piscator $\mathrm{H}, 1-12$.

Rijavec, L, 1973. Biology and Dynamics of Pagellus Coupei (Dieuz. 1960), Pagrus Ehrenberg (Val. 1830) and Dentex canariensis (Poll. 1954) in Ghana Waters. Doc. Soient. Centre Recit. Oc'om, R. Attldj. 4, 41-17.

Russell, B, Carpenter, KE, 2014. Pagellus bellottii. In: IUCN Red List of Threatened Species 2014. e.T170162A1285147.http://dx.doi.org/10.2305/IUCN.U K.20143.RLTS.T170162A1285147. (Accessed July 2016).

Sesay, LD, 2014. Assessment of the status of ten commercially important demersal finfish and some biological aspecrts of two species in the coastal waters of Sierra Leone. M.Phil thesis, University of Sierra Leone, Sierra Leone.

Showers, PAT, 1995. Abundance and distribution of the Sparidae in Sierra Leone waters-An ecological interpretations. PhD thesis, University of Sierra Leone, Sierra Leone.

Tomlinson PK, Abramson, NJ, 1961. Fitting a Von Bertanlaffy growth curve by least squares. Fisheries Bulletin 116, 69 .

Wehye, AS., Ofori-Danson, PK, Lamptey, AM, 2017. Population dynamics of Pseudotolithus Senegalensis and Pseudotolithus Typus and their implications for management and conservation within the coastal waters of Liberia. Fisheries and Aquaculture Journal 8, 201. doi: 10.4172/2150-3508.1000201.

Wetherall JA, 1986. A new method for estimating growth and mortality parameters from length-frequency data ICLARM Fishbyte, 4, 12-14.

Yarba, OL., Ghorbel, M, Bouain, A, 2004. Age et croissance de Pagellus bellottii (Sparidae) des côtes Mauritaniennes. Bulletin of INSTM Salammbô 31, 35-42. 